\title{
Milton Friedman's presidential address at 50
}

\author{
Thomas Palley* \\ Independent Economist, Washington, DC, USA \\ Matías Vernengo* \\ Professor, Bucknell University, Lewisburg, PA, USA
}

Milton Friedman's American Economic Association (AEA) presidential address, 'The role of monetary policy,' was published 50 years ago in the 1968 Papers and Proceedings issue of the American Economic Review. Friedman's influence as an economist is undeniable and he is widely viewed, together with John Maynard Keynes, as the most important macroeconomist of the twentieth century. His contributions were extensive but, in our view, his AEA address has been the most influential.

In that address, Friedman introduced the concept of the natural rate of unemployment (NRU), which can be paired with Wicksell's notion of a natural rate of interest. The idea of the NRU represents a clear theoretical return to pre-Keynesian views, which Friedman had tacitly defended throughout his career and which were connected to his revival of the quantity theory of money in his book, A Monetary History of the United States, co-authored with Anna Schwartz. However, as shown in the monetarist debates of the 1960s, his earlier work on monetary theory lacked a convincing macroeconomic theory in which to ground his policy conclusions.

Friedman's address provided that missing theory by revamping the Keynesian IS-LM model to include a Phillips curve which was vertical at the NRU in the long run. Thus, not only did Friedman fill the gap in his own thinking, he also co-opted the Keynesian macro model.

The idea of the NRU provided an anchor for the simple monetary rules that have since come to dominate the theory of monetary policy. In effect, in the same way that Keynes's The General Theory of Employment, Interest and Money had done a generation earlier, Friedman's address provided both a theoretical framework and a simple policy prescription. That framework and prescription fell on fertile ground in the 1970s, when the neoliberal revolution swept through the political landscape.

It should be clear that Friedman's monetary rule for a constant rate of moneysupply growth never became dominant, and these days most central banks are concerned with rules about the rate of interest. However, Friedman's concept of the NRU remains overwhelmingly dominant within the profession and has proven incredibly resilient. Indeed, the founding of the Review of Keynesian Economics (ROKE) was to some extent a reaction to the dominance of the Friedmanite notion of an NRU.

The current symposium aims to reflect on the reasons for the success of Friedman's address and its consequences for macroeconomic analysis and policy. We hope the contributions of this distinguished group of economists will enrich understanding of the current macroeconomic consensus. Beyond that, speaking from a personal point of view, we hope it will help pave the way for wider engagement with Keynesian responses to Friedman's natural rate hypothesis, leading to reassessment of the realworld relevance of the idea of a natural rate of unemployment.

* Co-editors of the Review of Keynesian Economics. 
420 Review of Keynesian Economics, Vol. 6 No. 4

Lastly, we would like to thank Louis-Philippe Rochon (emeritus co-editor) for his initial suggestion that $R O K E$ organize a symposium marking the 50th anniversary of Friedman's AEA presidential address and for his contributions to this issue.

\section{REFERENCES}

Friedman, Milton (1968), 'The role of monetary policy,' American Economic Review, 58(1), $1-17$.

Friedman, Milton and Anna Jacobson Schwartz (1963), A Monetary History of the United States, 1867-1960, Princeton, NJ: Princeton University Press for the NBER.

Keynes, John Maynard (1936), The General Theory of Employment, Interest and Money, London: Macmillan. 